\title{
Correction to: Gender Discrimination and Excess Female Under-5 Mortality in India: A New Perspective Using Mixed-Sex Twins
}

\author{
Ridhi Kashyap ${ }^{1} \cdot$ Julia Behrman ${ }^{2}$ \\ (C) The Author(s) 2020
}

\section{Correction to: Demography \\ https://doi.org/10.1007/s13524-020-00909-0}

The article Gender Discrimination and Excess Female Under-5 Mortality in India: A New Perspective Using Mixed-Sex Twins, written by Ridhi Kashyap \& Julia Behrman, was originally published electronically on the publisher's internet portal on 25th September without open access due to an administrative processing error by the publishing team. This has now been corrected and as a result the copyright of the article has changed to (C) The Author(s) 2020 and the article is forthwith distributed under the terms of the Creative Commons Attribution 4.0 International License (http:// creativecommons.org/licenses/by/4.0/), which permits use, duplication, adaptation, distribution and reproduction in any medium or format, as long as you give appropriate credit to the original author(s) and the source, provide a link to the Creative Commons license and indicate if changes were made.

Publisher's Note Springer Nature remains neutral with regard to jurisdictional claims in published maps and institutional affiliations.

The online version of the original article can be found at https://doi.org/10.1007/s13524-020-00909-0

Ridhi Kashyap

ridhi.kashyap@nuffield.ox.ac.uk

1 Department of Sociology, Nuffield College, and Leverhulme Centre for Demographic Science, University of Oxford, Oxford, UK

2 Department of Sociology and Institute for Policy Research, Northwestern University, Evanston, IL, USA

Published online: 25 November 2020 